\title{
O Teatro Do Mundo Como Assembleia Congelada - A prova de fogo de maio de 1968 no Brasil
}

\author{
Ivan Delmanto \\ Universidade de São Paulo - USP, São Paulo, Brasil \\ E-mail: ivandelmanto@yahoo.com.br
}

\section{Resumo}

O artigo analisa uma peça de Consuelo de Castro, A Prova de fogo, e procura revelar, nas modificações realizadas a partir dos modelos originais do drama moderno e do teatro épico europeus, que a obra pode ser melhor compreendida a partir das tensões entre regime militar brasileiro e movimento estudantil, deflagradas durante o ano de 1968.

Palavras-chave

Dramaturgia. Teatro Brasileiro. Teoria Crítica. Movimento Estudantil.
Abstract

The article analyzes a play by Consuelo de Castro, A prova de fogo, and tries to reveal, in the modifications made from the originals models of European modern drama and epic theater, that the work can be better understood from the tensions between the Brazilian military regime and the student movement, which broke out in 1968.

Keywords

Dramaturgy. Brazilian Theater. Critical Theory. Student Movement 


\section{Prólogo encarcerado na} Rua Maria Antônia:

Durante a ocupação estudantil da Faculdade de Filosofia, Ciências e Letras da USP, em 1968, a dramaturga Consuelo de Castro, então aluna de sociologia e atuante no movimento estudantil, escreve sua primeira peça teatral, Prova de fogo. O texto, censurado meses depois de escrito, só foi encenado em 1993, quando a USP recuperou o prédio na rua Maria Antônia, que havia sido destruído pela batalha com os alunos da Mackenzie (faculdade que ficava no prédio em frente) e pela invasão policial em outubro de 1968. A narrativa da peça é simples, marcada pela unidade de ação e pela progressão dramática: um grupo de estudantes ocupa a Faculdade de Filosofia, protestando contra a reforma educacional promovida pelo governo e contra a escalada autoritária do regime militar. A polícia profere um ultimato de três dias para que o prédio seja desocupado: a ação transcorre durante esses três dias, aproveitando material histórico, biográfico e ficcional. No fim, os universitários recusam-se a abandonar o prédio, que é invadido pelos policiais. Antes de consumar a invasão, as forças militares haviam assassinado um estudante durante uma passeata, única ação da peça que transcorre fora do prédio ocupado, sendo representada por recursos épicos: a inserção de boletins de rádio e diálogos de teor narrativo, em que os personagens refletem sobre a repressão ao movimento estudantil e sobre a morte do colega. Segundo Consuelo, em entrevista concedida quase trinta anos depois, "a batalha da Maria Antonia culminou um processo de isolamento e pressão de meses. Por parte da polícia do Estado e do Comando de Caça aos Comunistas (CCC). (...) Foi ali que escrevi
Prova de Fogo. No olho do furacão e no furacão propriamente dito". (CASTRO, 1994).

Partiremos, neste artigo, da hipótese de que Prova de Fogo só pode ser compreendida com profundidade se pudermos refletir sobre os acontecimentos históricos de maio de 1968 no Brasil, expressos não só no conteúdo da peça (a batalha da rua Maria Antônia, a morte do estudante José Guimarães, as ocupações estudantis de Universidades em todo país) mas, principalmente, no tecido formal da peça. Em 1968 o TUSP ${ }^{1}$ estreava Os Fuzis da Senhora Carrar, de Bertolt Brecht, com direção, cenários e figurinos de Flávio Império, e lia Prova de Fogo. A peça acabava de ser escrita e o grupo pensava em montá-la, mas a censura abortou o projeto. A obra de Brecht funcionou como modelo para a escrita dramatúrgica de Consuelo naquele ano e procurarei demonstrar que nos deslocamentos e desmoronamentos promovidos pela autora, em relação a Os Fuzis de Brecht, é possível detectar aspectos importantes da formação histórica brasileira, cicatrizes e fraturas ainda expostas daquele ano que terminou encarcerado pelo Ato Institucional de número cinco.

\section{Maio de 1968 brasileiro e formação histórica negativa}

Para Marcelo Ridenti (2002), nos anos anteriores a 1968, foram vitoriosas ou estavam

110 Teatro dos Universitários de São Paulo (TUSP) surgiu em 1966, reunindo estudantes do curso de arquitetura e da faculdade de filosofia, ciências e letras. A primeira montagem do grupo ocorre em 1967, com a peça Exceção e a Regra, de Brecht, dirigida por Paulo José. A temporada se deu em sindicatos, fábricas e grêmios estudantis. A segunda montagem do TUSP foi Os Fuzis da Sra. Carrar, agora dirigida por Flávio Império. Estreou em 3 de maio de 1968, no teatro Ruth Escobar em São Paulo e, diferentemente da anterior, era voltada ao público estudantil. (Cf. MACHADO, 2014, p.113-124). 
ocorrendo inúmeras revoluções de libertação nacional: a revolução cubana de 1959, a independência da Argélia em 1962, e a Guerra do Vietnã. "O sucesso dessas revoluções é fundamental para a compreensão das lutas e do ideário contestador de 1968" (2002, p. 135). Por outro lado, os revoltosos de 1968 criticavam o modelo soviético de socialismo, "tido como burocrático e acomodado à ordem internacional estabelecida pela Guerra Fria, sem incentivar as transformações sociais, políticas e econômicas necessárias para se chegar ao comunismo" (idem, ibd.). Movimentos de protesto e mobilização política surgiram por toda parte: "das manifestações nos Estados Unidos contra a Guerra do Vietnã à Primavera de Praga; do maio libertário dos estudantes e trabalhadores franceses ao massacre de estudantes no México"(Idem, p. 136). Entre todos esses movimentos sociais, o mais destacado foi o dos estudantes, que se mobilizaram em todas as partes do mundo. Maria Ribeiro do Valle destaca uma matéria da revista brasileira Visão, de julho de 1968:

Quem desce do Aeroporto do Galeão, depois de uma estada relativamente curta no estrangeiro, verifica que o Brasil se encontra no fio da história: a crise estudantil é comum ao Rio de Janeiro, a Nova York, a Paris, a Belgrado e a Roma. Logo se destaca a constante mais evidente do conflito: a reforma universitária". (VALLE, p. 162, 2008)

O combate pela reforma universitária surge na peça de Consuelo de Castro, logo no primeiro quadro:

CEBOLINHA: Se não resistirmos, eles nos massacram de outras maneiras... Acabam com nosso Grêmio, mandam os professores de esquerda pro olho da rua. (...) O governo e aquele filho da mãe do ministro da educação mandam para cá um bando de gringos para cagar regras pra cima da gente. $\mathrm{O}$ acordo MEC-USAID. (ao ouvir as palavras MEC-USAID o alvoroço aumenta.) TODOS - Abaixo o MEC-USAID... Fora os gringos...A reforma educacional é nossa. (CASTRO, 1989, p. 33)

O Acordo MEC-USAID passou a ser chamado assim devido à série de convênios assinados entre o Ministério da Educação (MEC) e a United States Agency for International Development (USAID) a partir do Golpe Militar de 1964. O Acordo determinava uma reforma em todos os níveis de ensino brasileiros, adotando-se o modelo norte americano, especialmente no ensino superior. "Pelo papel estratégico deste nível, a reforma visava uma formação técnica mais ajustada ao plano desenvolvimentista e econômico brasileiro, em consonância com a política norte-americana para o país". (FRANZON, 2015, p. 40621) Pelo convênio MEC-USAID de 1967 foi estabelecida a reforma em todos os níveis de ensino, orientada por técnicos dos Estados Unidos, e impondo ainda a obrigatoriedade do ensino da língua inglesa desde o primeiro ano escolar. Houve fortes reações do Movimento Estudantil contrárias à intervenção dos consultores norte-americanos, vendo na sua presença uma forma de submissão da soberania nacional aos interesses do imperialismo.

No entanto, e podemos testemunhar esse panorama em Prova de fogo, o contexto das revoltas de 1968 era mais amplo que apenas o das reformas universitárias. Os movimentos estudantis tiveram suas especificidades, ocorrendo em países e realidades diferentes, cada um dos quais com sua própria organização social e educacional, enfrentando conjunturas políticas diversas. Além da defesa da Universidade como espaço público de produção de 
conhecimento, no entanto, havia vários aspectos históricos supranacionais, comuns aos vários países onde ocorreu agitação estudantil. "Por isso, alguns chegam a falar numa Internacional Estudantil espontânea, movimento organizado em termos internacionais, mas com inúmeras afinidades entre seus componentes". (RIDENTI, 2002, p. 142).

A tradição marxista brasileira da segunda metade do século XX - com sua crítica da epistemologia e do contemplativo, sua denúncia da unidimensionalidade e da reificação, por meio da recepção da obra do filósofo Herbert Marcuse (Eros e civilização, principalmente) - enriquecerá a análise crítica desse contexto histórico com uma identificação entre modernidade e capitalismo, muitas vezes por meio de uma leitura precipitada da filosofia que chegava da Europa. Segundo Zuenir Ventura (1988),

um alemão de 70 anos, exilado nos Estados Unidos, ia ser o guru da geração de 68 em quase todo o mundo: Herbert Marcuse. Marcuse, um dos chamados "3 M de 68" - os outros eram Marx e Mao -, invadiu a imaginação dos jovens brasileiros através da imprensa mesmo antes de desembarcar nas livrarias. Ele chegou por meio de dois livros, Eros e civilização e Ideologia da sociedade industrial, que permaneceram nas listas debest sellers durante meses. O terceiro a chegar, já em outubro, Materialismo histórico e existência, esgotou 1.500 exemplares em poucos dias. (p. 65)

$\mathrm{Na}$ verdade, em análise posterior e livre das limitações do contexto da recepção brasileira do filósofo, Isabel Maria Loureiro (2005) constata que

Marcuse teve no Brasil uma péssima recepção. Nas décadas de 1960/1970, época de seu grande sucesso junto aos estudantes rebeldes, acabou sendo identificado unilateralmente com a contracultura, o que gerou incompreensões por todos os lados. As escolas católicas, vendo nele um arauto da permissividade sexual e da liberação das drogas, proibiam a leitura de suas obras. A esquerda comunista interpretava sua crítica à cultura ocidental como irracionalista. (p. 9)

Para Carlos Nelson Coutinho (2011), a chamada Escola de Frankfurt foi recebida no Brasil como "estímulo intelectual à contracultura irracionalista", e sua recepção iniciou-se com muitos livros de Marcuse, que foram então publicados ao lado de "importantes ensaios de Benjamin, Adorno e Horkheimer". Esse processo foi determinado pela "peculiar situação brasileira dessa segunda metade dos anos de 1960", e dependeu dessa situação que Marcuse "tenha desfrutado, na vida intelectual brasileira da época, de uma influência incomparavelmente superior à de seus companheiros de Escola" (p. 73). Marcuse chegava ao Brasil "no momento em que um amplo setor da intelectualidade de esquerda não julgava mais encontrar nas posições do PCB (e da cultura marxista que lhe era próxima) uma resposta adequada aos desafios da realidade" (p. 74). Apesar de fornecer uma "crítica concreta das tendências totalitárias que vê florescer no capitalismo organizado da época, indicando com precisão suas raízes culturais", uma leitura apressada e distorcida da obra de Marcuse gerou uma situação cultural em que "Marcuse tornou-se fonte de inspiração para os movimentos da chamada contracultura, ou, mais precisamente, daquela versão tropicalista da de Calderoni contribui para forma um vaudeville em ruínas, mas mesmo assim quase infantilizante, ou consegue constituir criticamente uma comédia social romântico-anticapitalista que floresceu e se desenvolveu aqui". (COUTINHO, 
2011, p. 76)

Em cena do Quadro 1 de Prova de fogo é possível identificar essa espécie de recepção irracionalista da obra de Marcuse no Brasil:

CEBOLINHA - Com essa história de doutrinação política, o Zé vai comendo uma por uma. Você já viu uma coisa igual? Onde, em que país, os líderes estudantes se metem a gavião desse jeito? (...)

JÚLIA - Sabe como? É simples. Ele diz que o preconceito sexual atrasa a revolução.

FREDERICO - Que é que a ideologia política tem a ver com cama?

JÚLIA - São os mistérios do mundo! Marcuse explica. (CASTRO, 1989, p. 51)

O clichê "Marcuse explica" parece sintetizar o contraditório processo de aclimatação das ideias do filósofo da teoria crítica no Movimento Estudantil brasileiro. As dimensões estética e erótica da existência representam, para Marcuse, uma "grande recusa" da realidade existente e a exigência de um outro mundo. $\mathrm{O}$ amor autêntico preserva visões de emancipação e assim torna-se parte do projeto radical de transformação social e de transcendência. Nos reinos da arte e do amor seria possível transcender a banalidade e a opressão da vida diária e viver em uma dimensão superior. Procurando recuperar o significado e função originais da "estética", o filósofo parte da associação íntima entre "prazer, sensualidade, beleza, verdade, arte e liberdade - uma associação revelada na história filosófica do termo estético" (MARCUSE, 2010, p. 156). A tarefa seria reconciliar "na realidade da liberdade, as faculdades 'inferiores' e 'superiores' do homem, sensualidade e intelecto, prazer e razão" (Idem, ibd.). Mas essa relação complexa entre a necessária emancipação do sentimento amoroso e a resistência aos ditames do capitalismo surge, nos jovens personagens da peça, como espécie daquela "versão tropicalista da Kulturkritik romântico-anticapitalista" mencionada acima por Coutinho, que une, no entendimento precipitado dos estudantes, "ideologia política" e "cama". Para Marcuse (1989), no entanto, estava em jogo "a visão de uma ordem não-repressiva em que o mundo subjetivo e objetivo, o homem e a natureza, se harmonizam"(p.172). Como se procurasse seguir os passos dessa reconciliação entre "mundo subjetivo e objetivo", podemos encontrar, na fatura formal de Prova de fogo, uma coexistência entre os universos público, épico e objetivo, e privado, subjetivo e dramático, em uma junção de procedimentos e gêneros teatrais que expressa aspectos históricos decisivos não só do momento em que a peça foi escrita, mas da formação truncada do país.

\section{Forma híbrida e dialética truncada}

Escrita em um momento de regressão do movimento operário europeu, ameaçado pela ascensão do fascismo, a dramaturgia de Os fuzis da Senhora Carrar, de Brecht, procurou, já na década de 1930, superar essa dicotomia entre universo subjetivo e objetivo, que norteou, desde a Estética Hegel, a reflexão sobre o gênero dramático. Em um fragmento que tem o nome sugestivo de "É possível fazer teatro épico em qualquer lugar?" (1976), Brecht responde à pergunta do título negativamente: "Também o moderno teatro épico está ligado a certas e determinadas tendências. Não pode ser, de forma alguma, feito onde quer que seja" (p. 54). Para o dramaturgo alemão, o teatro épico estaria ligado à experiência histórica 
do movimento operário europeu: "Este tipo de teatro pressupõe, além de um determinado nível técnico, um poderoso movimento na vida social" (Idem, ibd.). Talvez por isso Brecht classifique Os fuzis da Senhora Carrar como um recuo aos ditames da forma dramática para conseguir a comunicação com um público não mais formado por "especialistas" de um robusto movimento operário, acostumado às questões e soluções formais do teatro épico, mas sim tentando atingir com urgência espectadores desnorteados, acostumados à identificação e à catarse do drama, em meio às trágicas derrotas obtidas durante o cataclisma da Guerra Civil espanhola. Sobre essa opção de utilizar-se do modelo dramático, Brecht afirma que: "As desvantagens dessa técnica podem, em certa medida, ser contrabalançadas ao representar a peça junto com um documentário mostrando os eventos na Espanha ou algum evento de propaganda" (Idem, p. 93)

Utilizando as unidades de ação, de tempo e de lugar, Os fuzis da Senhora Carrar trata da metamorfose de uma inicialmente despolitizada dona de casa, em nove cenas ocorridas em sua cozinha, em uma aldeia de pescadores da Andaluzia, no sul da Espanha. "O tempo da narração abrange acontecimentos concretos: a greve dos mineiros de Oviedo, nas Astúrias, no norte do país, no ano de 1935 e as conseqüências em 1936, que resultam na morte de Carlo; e os anos de fome de 1898 e 1899, durante os quais sucumbiram dois filhos pequenos da senhora Perez" (ROCHA, s/d, p. 5). $A$ peça foi influenciada por reportagens sobre a presença de mulheres no front, e também "pela tragédia de uma mãe enlutada pela perda de vários familiares afogados no mar, publicada no jornal de Copenhague" (Idem, ibd.). O general Franco, o General Mola e o Gene- ral Queipo de Llano, que fala à população por meio de um programa de rádio noturno, e o Arcebispo de Canterbury são personagens históricas citadas na peça.

Essas inserções épicas de um programa de rádio, responsáveis por narrar e introduzir o contexto do mundo objetivo, externo ao diálogo intersubjetivo dos personagens, constituem, salvo engano, o modelo para procedimento épico similar empregado na peça de Consuelo de Castro:

O rádio: em santa cruz os estudantes queimaram um carro da polícia. Apedrejaram o consulado americano e diversos vidros do banco da américa foram danificados. Esta carnificina precisa acabar. Ou o governo toma uma providência urgente, ou este país, tão católico, tão honrado, acaba caindo nas mãos dos comunistas. (CASTRO, 1989, p. 73)

A utilização do destaque em itálico das palavras e das letras maiúsculas, procura separar o material épico, contido na voz do Rádio, da progressão dramática da peça, tentando distinguir entre universo público e privado na estrutura formal da dramaturgia. Assim como na peça de Brecht, fatos históricos reais baseiam as ações de Prova de Fogo.

No mês de julho de 1968, várias faculdades são ocupadas pelos estudantes. "Exemplar é o caso da Faculdade de Filosofia da USP, que, tendo funcionado como QG da movimentação estudantil durante todas as férias, se recusa a reiniciar as aulas em agosto por considerar a universidade arcaica incompatível com a realidade brasileira" (VALLE, 2008, p.166). Essa longa ocupação realizada pelos estudantes da Filosofia da USP aguçou a tradicional rivalidade com o centro universitário da direita paulista, a Mackenzie, que ficava na mesma rua. 
A repressão militar explorou essa rivalidade, encastelando seus agentes - com a contribuição da milícia para-militar Comando de Caça aos Comunistas (CCC) - no prédio da universidade privada, promovendo uma verdadeira batalha contra os ocupantes da USP, com troca de tiros, pedras, vidros de ácido sulfúrico e coquetéis Molotov. Deste choque resultou a morte do secundarista José Guimarães, representado na peça pelo personagem Luís. Sob a direção de José Dirceu (o Zé, protagonista de Prova de Fogo que, como seu homônimo real, recebe o apelido de "Ronnie Von das massas"), presidente da UEE-SP, os estudantes foram às ruas em uma passeata que queimou carros e apedrejou bancos, exatamente como narrado na inserção do Rádio citada acima.

No entanto, diferentemente do que ocorre no modelo de Brecht, há um deslocamento fundamental na forma dramática construída pela dramaturga brasileira: talvez na busca, sugerida pela obra de Marcuse, de conciliar sentimento amoroso com luta política revolucionária, os personagens de Prova de fogo corroem, negam a cada cena uma estrutura formal épica, baseada na forma perpétua e congelada de uma grande Assembleia. Se na peça de Brecht a forma dramática é interrompida pela invasão épica das narrativas do rádio, no texto brasileiro, pelo contrário, uma estrutura épica inicial é roída por conflitos do universo da sentimentalidade. Em Os Fuzis da Senhora Carrar, o espaço público, que surge por meio das inserções épicas, está mais do que separado e destacado no mundo privado dos conflitos familiares: há o aprofundamento da contradição entre estes dois âmbitos, que move toda a narrativa da peça. Brecht, quando relata o processo de encenação da peça, deixa claro o quanto a contradição entre épico e dramático era essencial para a engrenagem de Os Fuzis:

\begin{abstract}
Tínhamos descoberto o erro. Helene Weigel fizera que a Senhora Carrar cedesse visívelmente a cada golpe e sofresse um colapso, ao sobrevir o mais violento. Em vez disso, ela tinha de mostrar no seu desempenho como a Carrar vai progressivamente se endurecendo a cada golpe que a abala, e, repentinamente, sucumbe ao derradeiro. (...) "É espantoso", disse Brecht, após o ensaio ter confirmado a acuidade das nossas conjecturas, "é espantoso que, a cada vez, seja necessário repetir este mesmo esforço, para se observarem as leis da dialética!" (BRECHT, 1978, p.155)
\end{abstract}

A contradição aparece na construção da protagonista: os golpes que abalam a senhora Carrar fazem parte do universo externo, histórico, que invade o espaço familiar e privado do drama: seu filho morre metralhado durante a Guerra Civil espanhola. Quando seu mundo subjetivo sucumbe, Carrar decide assumir essa contradição entre seu mundo individual e o contexto histórico, aceitando entregar os fuzis do marido morto, que escondia em casa, abandonar o lar protegido e partir para a frente de combate.

Por mais que tenha tentado, como vimos acima, destacar e separar o material épico do dramático, a relação entre esses universos, em Prova de Fogo, não é da ordem dialética da contradição, como no modelo épico-dramático de Brecht, mas da dissolução, da confusão entre esses territórios. Inicialmente, a peça é construída sob uma grande cena única, dividida em três quadros, que estende-se em uma grande Assembleia estudantil, que parece não ter fim:

ROSA -Questão de ordem. Quero lembrar aos colegas que a lista dos orado- 
res inscritos já chega aos vinte e três. E são dez horas. Proponho que Freitas encerre a lista de oradores e encaminhe a votação das duas propostas que estão sobre a mesa. (CASTRO, 1989, p. 41)

O diálogo entre os personagens persiste mediado pela longa Assembleia noite adentro, até o final da peça:

ZÉ - Quando acabar essa falação, me dá a palavra. Tenho uma coisa séria a discutir com todo mundo. (CASTRO, 1989, p. 99)

Entretanto, enquanto a narrativa da ocupação da faculdade pelos estudantes transcorre, cenas do universo sentimental dos personagens, pouco a pouco, dissolvem o espaço épico da Assembleia, em que um coro de estudantes discute questões de interesse público sobre a ameaça de invasão das forças da repressão e sobre a passeata esmagada com violência pelos militares. O coro de estudantes, na medida em que a peça avança, fraciona-se e os personagens individualizam-se por meio de seus conflitos sentimentais:

ROSA - Bom. Agora só sobramos nós. JÚLIA - Rosa, você vai lá fora arrumar as barricadas. Eu e o zé vamos juntos pro telhado coordenar a segurança.(...) ZÉ - Ela não vai. (...) A Rosa não vai a lugar nenhum. (...) Eu disse que preciso falar com a Rosa, e não tenho nada a resolver com você. Não insista.

JÚLIA - não tem nada a resolver comigo? Não tem?

ZÉ - Não.

JÚLIA - Pois eu vou contar pra tua Rosinha, então (olha friamente para Rosa). Sabia, menina, que estou grávida de três meses e que o pai desta criança chama-se José Freitas? Sabia? (CASTRO, 1989, p. 47)

Valmir Santos, em crítica sobre uma mon- tagem de 1997 da peça, identificou esse movimento entre mundos público e privado: "A força da união, com perdão do clichê, é a essência da peça de Consuelo de Castro. Seu olhar é coletivo. Quando cria atalhos para os relacionamentos amorosos, os diálogos perdem o brilho". (SANTOS, 1997). Os diálogos "perdem o brilho" não por uma incapacidade técnica da dramaturga, mas porque a estrutura épica da peça, um coro de participantes de uma Assembleia, não comporta e não avança por meio de diálogos dramáticos. Talvez a impressão de falta de brilho venha do congelamento da Assembleia, promovido pelas interrupções dramáticas, que não servem à narrativa pública principal, da ocupação e do cerco da polícia. Ao tentar conciliar sentimento erótico e revolução, a partir do pensamento de Marcuse, tão em voga em 1968, Consuelo de Castro dissolve a atividade revolucionária dos estudantes em seus conflitos sentimentais, congelando a narrativa a todo instante, chegando a situar o que era o enredo principal como pano de fundo para o triângulo amoroso juvenil entre Zé, Rosa e Júlia. No fim, não há nem contradição e nem reconciliação entre âmbitos coletivo e individual há apenas dissolução e mistura de um no outro. Mas parece-me que justamente essa aparente fragilidade do texto é capaz de nos revelar contradições de amplo fôlego histórico, situadas para além do ano de 1968 brasileiro.

\section{Revelando os negativos da Assembleia congelada}

Comparando a transição europeia da forma dramática para o teatro épico a partir de Brecht, Peter Szondi aponta que, pela inser- 
ção de elementos econômicos e pelo deslocamento do acontecimento dramático da esfera da ação dramática efetuada por personagens individuais para a esfera do processo social supraindividual, que precisa ser representado como processo social, ocorre uma modificação formal. A peculiaridade da forma de Prova de fogo reside na simultaneidade na representação da esfera privada e familiar e de processos sociais supraindividuais, sem que haja fronteira ou separação entre esses aspectos. Essa simultaneidade formal do público e do privado, do épico e do dramático, como duas faces de uma moeda que se interpenetram e se invadem, talvez expresse aspectos bastante específicos da sociedade brasileira.

A esse respeito, podemos retomar Max Weber, para quem as burocracias são essencialmente sistemas de normas. A figura da autoridade é definida pela lei, que tem como objetivo a racionalidade e a coerência entre meios e fins. O tipo ideal de burocracia baseia-se na formalidade e apresenta três características essenciais: as pessoas são ocupantes de cargos ou posições formais, com alguns dos cargos gerando figuras de autoridade. A obediência é devida aos cargos, não aos ocupantes, e todas as pessoas seguem a lei. A burocracia tem como segundo princípio a impessoalidade: as burocracias são formadas por funcionários que, como fruto de sua participação, obtêm apenas os meios para sua subsistência. Tal profissionalismo geraria a terceira e última característica essencial da burocracia: a administração burocrática como a forma mais racional de exercer a dominação. Para tal, a burocracia segundo Weber refere-se a um sistema marcado pela divisão do trabalho; pela hierarquia claramente definida; por regras e regulamentos detalhados, possibilitando 0 exercício da autoridade e a obtenção da obediência com precisão, continuidade, disciplina, rigor e confiança.

Para o negativo de tal processo, é possível encontrar em Raízes do Brasil, de Sérgio Buarque de Holanda, uma interpretação da formação política, econômica e cultural do país inspirada em uma leitura de Max Weber a contrapelo. No Brasil, as normas que regem a formação das burocracias e dos Estados europeus já nasceriam invertidas, a partir de um processo de colonização que transformou o território em um enorme entreposto comercial das nações capitalistas avançadas. Por aqui, a sociabilidade da mercadoria seria a única lei absoluta, presente desde o surgimento das estruturas de poder, unindo burocracia e a mais despudorada bandalheira, cumprindo apenas a lei do valor.

Assim, para Sérgio Buarque, os princípios da burocracia estudados por Weber, em vez de dominação através da impessoalidade e da formalidade, gerariam no Brasil a figura do homem cordial. O homem cordial, fantasma e metáfora que permearia nossas relações sociais, é moeda que tem em uma face o favor e na outra a violência. A cordialidade do brasileiro alimentar-se-ia de uma estrutura de dominação baseada nas relações pessoais e no privilégio, em trocas de favores que, sob a nuvem do jeitinho, esconderiam a mais brutal crueldade, conjugando e justapondo a esfera pública ao âmbito privado sob a nuvem da cordialidade.

Na cena de Prova de fogo citada acima, a Assembleia de estudantes se dissolve, restando em cena três personagens, como anuncia Rosa: "Bom. Agora restamos nós." Acompanhamos, a partir daí, a trajetória individual desse "resto" do coro, em um triângulo amoroso 
que envolve a gravidez de Júlia. O que era de caráter público, torna-se sentimentalidade privada, o foco narrativo desloca-se de um conteúdo épico para um conteúdo dramático. Tal confusão entre dimensões pública e privada, característica do processo histórico brasileiro, emerge como um deslocamento formal - em relação ao teatro épico de Brecht - essencial ao retrato da formação do país, que está configurada na peça. Essa alegoria do indivíduo como resto do coletivo, que significa a diluição entre fronteiras, expressa um processo particular de dominação do trabalho, que tem na estratégia da cordialidade uma dupla face: de um lado a afetividade e, do outro, a mais brutal violência.

Consuelo de Castro fixou em sua peça a realidade histórica brasileira como uma contradição insolúvel, formada por opostos sem síntese viável, que se auto-suprimem. Parece-nos que a ruína do processo histórico brasileiro não podia ser plasmada sob a forma do teatro épico surgido na Europa, assim como, antes dele, Machado de Assis não pôde utilizar-se apenas da forma pura do romance europeu: "quando buscava prender as suas fábulas aos pontos de inflexão da história nacional, o romancista seguia a inspiração do realismo europeu, ou, por outra, tentava confeccionar algo semelhante no Brasil" (SCHWARZ, 2003, p. 324). Assim, a sucessão dos períodos da história brasileira, Independência, Abdicação, Regência, Maioridade, Conciliação, Gabinete Rio Branco etc. seriam os nossos equivalentes da periodização da história francesa pós-revolucionária, cujas etapas, muito nítidas e contrastantes, facultaram aos escritores daquele país uma experiência e uma representação muito mais nítida da historicidade do presente, incluído aí o âmbito privado. "Entretanto, ape- sar das muitas datas, o dinamismo histórico da literatura francesa não existe em sua obra" (Idem, ibd.).

O dinamismo histórico apontado por Roberto Schwarz nos autores do realismo europeu não existe na obra de Machado de Assis porque essa expressa a realidade brasileira. $A$ totalidade dialética presente em Os Fuzis da Senhora Carrar não pôde estar presente em Prova de fogo talvez porque nosso processo histórico se figurava, no momento em que a dramaturga escrevia, cercada pela polícia em uma Universidade ocupada, mais uma vez truncado:

em 1964, o golpe de força da direita truncou, sem encontrar, aliás, grande resistência, o vasto processo democrático a que o novo teatro procurava responder. (...) Por um acaso infeliz, ou melhor, por força da vitória da direita, a nova geração teatral alcançava a plenitude artística (...) no momento em que as condições históricas favoráveis a seu projeto haviam desaparecido" (SCHWARZ, 1999, p. 124)

Florestan Fernandes, ao caracterizar, em $A$ Revolução Burguesa no Brasil (1976), a natureza contra-revolucionária da modernização capitalista brasileira, considerou o golpe e a ditadura iniciada em 1964 como uma exacerbação da natureza autocrática da nossa classe dominante. Se na República de 1946 a dominação política foi feita com a manutenção de procedimentos típicos de uma democracia-liberal, dando à autocracia burguesa um aspecto velado, com a ditadura militar a burguesia continuaria seu "baile sem máscaras", concluía o sociólogo paulistano: "O povo não possuía nem mandatários responsáveis nem campeões leais no campo burguês; e quando o jogo democrático se tornou demasiado 
arriscado, os verdadeiros atores continuaram o baile sem máscaras. Em suma, não existia uma democracia burguesa fraca, mas uma autocracia burguesa dissimulada". (1976, p. 340)

Em diagnóstico complementar, no seu ensaio Crítica à razão dualista (2003), Francisco de Oliveira discutiu as condições sob as quais o regime ditatorial, ao contrário de estagnar a economia, foi eficiente em acelerar a acumulação capitalista no Brasil, aceleração essa que se tornou possível graças às condições de uma super-exploração da classe trabalhadora estabelecida pelo regime ditatorial: "o pós1964 dificilmente se compatibiliza com a imagem de uma revolução econômica burguesa, mas é mais semelhante com o seu oposto, o de uma contra-revolução. Esta talvez seja sua semelhança mais pronunciada com o fascismo, que no fundo é uma combinação de expansão econômica e repressão. (p. 67)"

Por meio do sufocamento da ocupação estudantil de uma Universidade sitiada - e cercada não em qualquer prédio, mas no edifício da faculdade de Filosofia - em que o espaço público é lentamente confiscado e desaparece graças à violência repressora, que permite apenas a sentimentalidade privada, Prova de Fogo expressa o momento histórico truncado que resultaria, no final daquele ano de 1968, no golpe dentro do golpe que significou a promulgação do Al-5. Neste sentido, o final da peça é emblemático:

PAULO - Torturaram sim. Não sei o que fizeram com ela. Sei que foi torturada. Não sei se arrancaram as unhas dela, se deram choque elétrico (Nervosíssimo, cheio do interrogatório do pessoal), se espancaram...sei que foi torturada. E abortou. (Zé cobre a cabeça, contorce-se, aflito, cheio de ódio) Teve uma violenta hemorragia. Quando eu saí de lá ela estava pas- sando muito mal. Custei a conseguir esta informação sobre ela, na enfermaria. Ela perdeu sangue à beça. Mas quando eu saí de lá ela não tinha morrido ainda.Não fiquei sabendo de mais nada. (CASTRO, 1989, p. 113)

A dissolução de fronteiras entre espaço público e privado, que a forma da peça expressa - e que revela um processo de formação histórica em que esses dois âmbitos emergem, desde a colonização, ausentes de separação -, aqui apresenta sua face cadavérica, decorrente da ascensão do absolutismo ditatorial do regime militar, transcorrida durante $o$ ano de 1968. O espaço público, disputado pelas revoltas estudantis desde maio, estaria, no final do ano, definitivamente barrado.

\section{Teatro do mundo}

Também em 1968, Gyorg Lukács, em um ensaio dedicado aos romances de Alexander Soljenitsin, O primeiro círculo e O pavilhão dos cancerosos, esboça as bases para uma reformulação de sua própria teoria da literatura contemporânea. Em vez de ver na narrativa realista de seu tempo uma simples continuação formal das velhas tradições do século XIX (ainda que "atualizadas" pelo emprego de técnicas de vanguarda), Lukács indica o modo pelo qual os novos pressupostos sociais e ideológicos do capitalismo tardio conduziram a uma modificação formal da estrutura romanesca, cujo centro não mais seria, como no romance tradicional, a figuração de uma "totalidade de objetos" - segundo a formulação hegeliana recolhida por Lukács -, mas de uma "totalidade de reações".

Segundo Hegel, 
a totalidade dos objetos que devem ser descritos, tendo em conta a relação íntima entre a ação particular e o terreno substancial sobre o qual se realiza; (...) Na poesia épica há lugar não só para a realidade nacional com que a ação se relaciona, mas também para as circunstâncias e os fatos exteriores e morais, de modo que se pode dizer que compreende a totalidade do que constitui a vida poética dos homens. (HEGEL,1997, p. 477- 478)

Para Hegel, não são apenas os fatos exteriores que são apresentados à luz deste conteúdo espiritual, mas os sentimentos mais íntimos, os fins e intenções, os atos individuais, justificados ou não, com fundamento ou sem ele, devem, também, ser ligados a este conteúdo e descritos nas suas relações com ele.

Lukács observa, por outro lado, que a inovação da "totalidade das reações", em relação à totalidade descrita acima por Hegel, reside no fato de que a unidade de lugar torna-se o fundamento imediato da composição, graças à criação de uma espécie de "teatro social" que agrupa homens diversos e os obriga a definições que eles não tomariam normalmente em sua vida cotidiana. Assim continua Lukács (1976): "esse teatro do mundo aparece, portanto, como o desencadeador efetivo e imediato de problemas ideológicos existentes por toda parte em estado latente, mas dos quais só se toma consciência, em sua totalidade contraditória, precisamente neste lugar" ( $p$. 34). Assim, teria desaparecido a possibilidade de uma fábula épica homogênea: "Porém, malgrado a ausência de fábula homogênea, e mesmo em consequência dessa ausência, reina uma excepcional intensidade de emoção épica" (p. 35). E aqui, algo que já identificamos na peça de Consuelo de Castro: "Relações épicas coerentes podem nascer de cenas particulares de natureza dramática, mas desprovi- das aparentemente de laços internos entre si. E essas relações podem igualmente se ordenar numa totalidade de reações a um vasto complexo de problemas de natureza épica" (p. 35)

Segundo Carlos Nelson Coutinho, "Lukács não viveu o suficiente para extrair todas as consequências desta sua nova formulação, o que teria implicado certamente a reavaliação de boa parte dos seus juízos sobre a literatura do século XX". Um autor como Thomas Mann, por exemplo, não mais lhe aparece - pelo menos a partir de A montanha mágica - como um continuador da narrativa tradicional, mas, ao contrário, como iniciador da nova forma do romance centrada na "totalidade de reações". No plano dramatúrgico, Prova de Fogo, ao apresentar a realidade sitiada brasileira, durante a escalada de violência do regime militar, configura um gênero inclassificável, em que os recursos épicos são dissolvidos nos procedimentos dramáticos. Talvez a peça de Consuelo de Castro só possa ser classificada a partir do conceito de "totalidade de reações" que, expostas por meio da concentração narrativa que se dá na unidade absoluta do espaço da faculdade sitiada, desenha o teatro do mundo de nosso baile sem máscaras ditatorial.

\section{Referências}

BRECHT, Bertolt. Escritos sobre teatro, vol.2. Buenos Aires: Nueva Visión, 1976.

BRECHT, Bertolt. Estudos sobre teatro. Rio de Janeiro: Nova Fronteira, 1978. 
CASTRO, Consuelo. "Democracia: Sonho Da Minha Juventude, Luta Da Minha Vida". Entrevista concedida ao Blog do Briguilino, em 22 de janeiro de 2014. Disponível em: https:// blogdobriguilino.blogspot.com/2014/01/democracia-sonho-da-minha-juventude.html. Consultado em 28/09/2018.

CASTRO, Consuelo. "Prova De Fogo". In: Urgência e Ruptura. São Paulo: Perspectiva, 1989.

COUTINHO, C. N. Dois momentos brasileiros da Escola de Frankfurt. In: Cultura e sociedade no Brasil. São Paulo: Expressão Popular, 2011.

FRANZON, Sadi. Os Acordos Mec-Usaid e a Reforma Universitária de 1968 -As Garras da Águia na Legislação de Ensino Brasileira. Anais do XII Congresso Nacional de Educação, 2015. Disponível em: educere.bruc.com.br/arquivo/pdf2015/21202_9057.pdf. Consultado em 25/09/2018.

HEGEL, G.W.F. Curso De Estética. O sistema das Artes. São Paulo: Martins Fontes,1997.

LOUREIRO, I. M. Herber Marcuse: Anticapitalismo e emancipação. In: Trans/Form/Ação, São Paulo, v. 28, n. 2, p. 7-20, 2005.

LUKACS, Gyorg. Solzhenitsyn. London: MIT Press, 1976.

MACHADO, R. (2014). Flávio Império e a montagem de os Fuzis da Senhora Carrar (1968). Sala Preta, 14(1), 113-124. https://doi. org/10.11606/issn.2238-3867.v14i1p113-124
OLIVEIRA, Francisco. Crítica À Razão Dualista. O ornitorrinco. São Paulo: Boitempo, 2003.

RIDENTI, Marcelo. "1968: Rebeliões E Utopias". In: REIS, Daniel Aarão; FERREIRA, Jorge; ZENHA, Celeste. O Século XX. Volume 3. Rio de Janeiro: Civilização Brasileira, 2002.

ROCHA, Denise. Brecht e a Guerra Civil Espanhola. S/D. Disponível em: http://www.abrapa. org.br/cd/pdfs/Rocha-Denise-Brecht.pdf

SANTOS, Valmir. "Prova De Fogo Atiça Utopia Juvenil”. Disponível em: http://teatrojornal. com.br/1997/10/prova-de-fogo-atica-utopia-juvenil/. Consultado em 12/09/2018.

SCHWARZ, Roberto. Posfácio. Contribuição a John Gledson. In: GLEDSON, John. Machado de Assis: ficção e história. São Paulo: Paz e Terra, 2003, p. 324.

SCHWARZ, Roberto. Sequências brasileiras. São Paulo: Cia. Das Letras, 1999, p. 124.

VALLE, Maria Ribeiro do. 1968: O Diálogo É A Violência. Movimento estudantil e ditadura Militar no Brasil. Campinas: Editora Unicamp, 2008.

VENTURA, Z. 1968: O ano que não terminou. Rio de Janeiro: Nova Fronteira, 1988. p. 65.

Recebido: 31/10/2018 Aprovado: 08/01/2019 